GRAŻYNA ŚWIĘTOCHOWSKA

Instytut Badań nad Kulturą

Uniwersytet Gdański
Images

vol. XXVII/no. 36

Poznań 2020

ISSN 1731-450X

\title{
Przestrzeń filmowa jako przestrzeń wiedzy. O filmach Ray i Charlesa Eamesów
}

\begin{abstract}
AвSTRACT. Świętochowska Grażyna, Przestrzeń filmowa jako przestrzeń wiedzy. O filmach Ray $i$ Charlesa Eamesów [The film environment as a sphere of knowledge. On Ray and Charles Eames films]. "Images" vol. XXVII, no. 36. Poznań 2020. Adam Mickiewicz University Press. Pp. 93-116. ISSN 1731-450X. DOI 10.14746/i.2020.36.06.

Through the whole period of their design output, Ray and Charles Eames used film as a tool. First, they referred to film when they tried to prove their artistic activity, then for the purposes of advertisement and finally, they got to large, highly-circulated global multimedia projects. Behind them were state and corporate subjects. In all film activities, they reveal an innovative attitude which negotiated the current techniques of production. Each time, they were able to create new value. They revolutionized advertising and educational films. In every attempt at this genre, they did not give up the humanistic approach. They presented scientific knowledge, offered in the form of standard high entertainment.
\end{abstract}

KEYWORDS: multiscreenings, cinema and design, cinema and architecture, world expo

Multimedialne dokonania Ray[1] (1912-1988) i Charlesa (19071978) Eamesów jeszcze za ich życia miały możliwość wydostania się poza Stany Zjednoczone za pośrednictwem trzech głównych kanałów: mebli sprzedawanych w Europie przez firmę Vitra, projekcji filmu Glimpses of the U.S.A. [Migawki z USA] w ramach moskiewskiej wystawy z 1959 roku oraz objazdowego monumentalnego projektu The World of Franklin and Jefferson [Świat Franklina i Jeffersona], wystawy z 1975-1977 roku przetłumaczonej na cztery języki i poza Nowym Jorkiem pokazywanej między innymi w Paryżu, Londynie i Warszawie. Produkty wyposażenia wnętrz i komunikaty wizualne dostarczane poza granice kraju, z którego sceną polityczną, przemianami gospodarczymi i społecznymi Eamesowie byli nierozerwalnie związani, dają jedynie niewielkie wyobrażenie o fenomenie małżeństwa projektantów, architekta i malarki, którzy przez niemal 37 lat[2] pracowali na rzecz demokratyzacji oferty wiedzy dla przeciętnego amerykańskiego obywatela. Jednak już nawet te trzy różnorodne osiągnięcia dużo mówią o zaufaniu, jakim obdarzani byli Eamesowie zarówno przez rząd amerykański, instytucje publiczne, jak i klientów komercyjnych.

[1] Właściwie Bernice Alexandra „Ray” Kaiser Eames.

[2] Za lata graniczne uznaję tu zaprojektowanie przez Charlesa pierwszego krzesła w konkursie ogłoszonym przez nowojorskie MOMA (1941) oraz rok jego śmier- ci (1978). Eames Office, prowadzone po śmierci męża przez Ray, nadal działało, ale kolejną dekadę charakteryzował raczej impuls porządkowania spuścizny niż prekursorskie decyzje projektowe. 


\section{4}

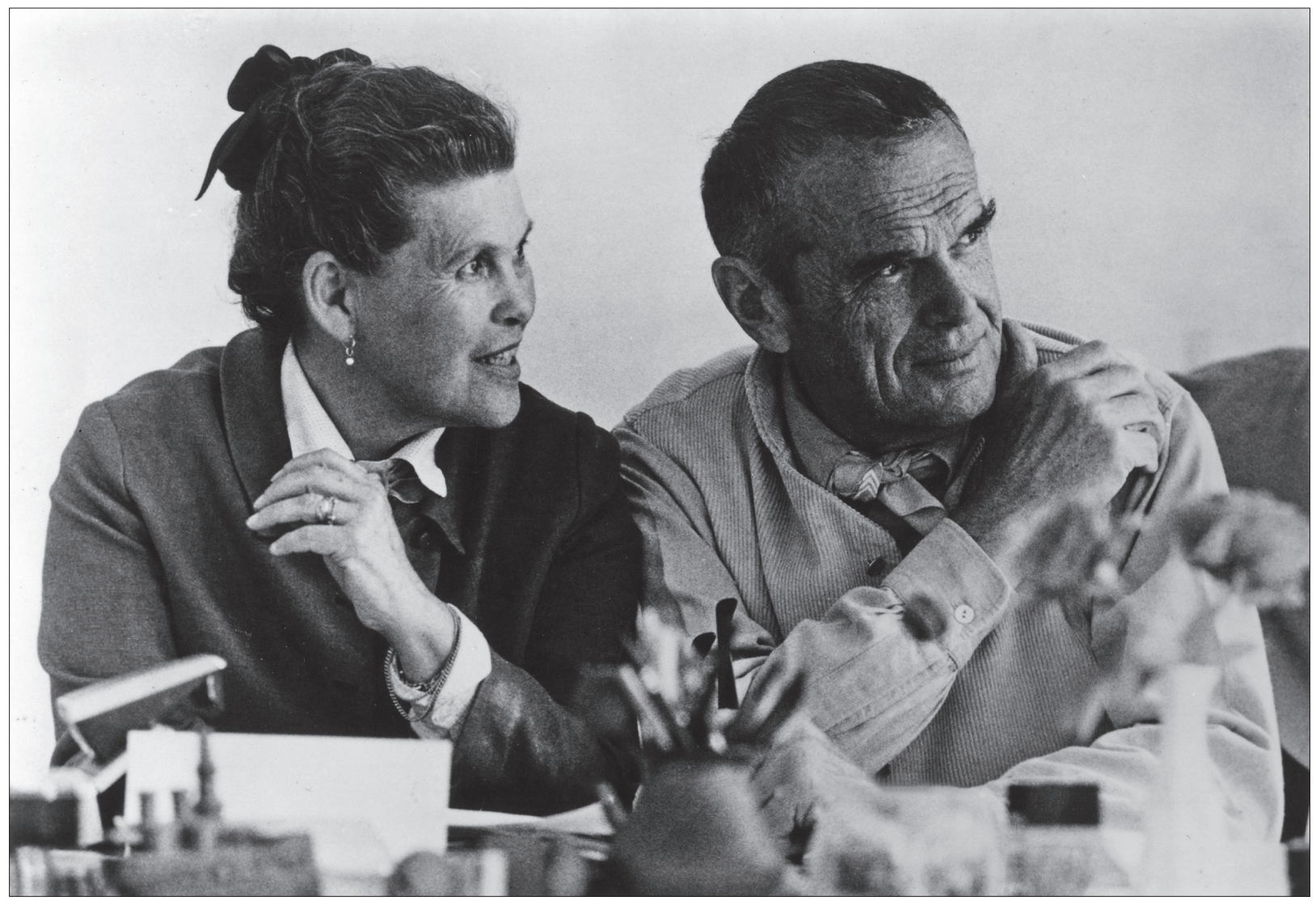

Il. 1. Ray i Charles Eamesowie

(c) Eames Office, LLC

Struktura, material i cel, czyli design
Zdaniem wielu badaczy, żeby pisać o filmowym dorobku Eamesów, najbardziej znanych i wszechobecnych projektantów przemysłowych XX wieku[3], trzeba pokrótce odnotować specyfikę ich zawodowej persony. Ta obejmowała nie tylko projektowanie mebli, realizację filmów czy kuratorstwo wystaw, ale też tworzenie zabawek, tkanin, oświetlenia, okładek, rzeźb oraz kreację nowoczesnego wizerunku dominujących na amerykańskim rynku koncernów. Żadne z małżonków formalnie nie ukończyło studiów. Charles mimo to przez dwa lata prowadził zajęcia dydaktyczne na Cranbrook Academy of Art, a Ray miała w zwyczaju powoływać się na nazwisko nowojorskiego malarza niemieckiego pochodzenia, Hansa Hoffmana, ekspresjonisty abstrakcyjnego, pod którego kierunkiem pracowała. Wydaje się, że obydwoje Eamesowie zawsze bardziej polegali na samodzielnej niż na formalnej edukacji. Charles wspominał, że już w dzieciństwie pasjonowała go lektura dostępnych instrukcji obsługi i opisy działania poszczególnych urządzeń[4].

W świadomości społecznej Eamesowie zaistnieli początkowo jako projektanci krzeseł[5]. Równie istotne miejsce w dopiero co rozwi-
[3] Ch. Pearce, Eames at the fair: A legacy of communication design, [w:] Meet Me at the Fair. A World's Fair Reader, red. L. Hollengreen et al., Pittsburgh 2014, s. 207.

[4] Wśród klientów sektora publicznego poza rządem Stanów Zjednoczonych znalazły się też rządy Indii czy Puerto Rico, a także sekretariat ONZ. Podaję za The World of Charles and Ray Eames, red. C. Ince, L. Johnson, London 2018.

[5] Pierwsze krzesło Charles zaprojektował wspólnie z Eero Saarinenem, architektem fińskiego pochodzenia, którego poznał jeszcze w czasie pobytu w Cran- 
jającej się karierze młodych projektantów spełniło rządowe zlecenie na zaprojektowanie sprzętu ortopedycznego - szyny usztywniającej złamania - dla amerykańskich żołnierzy włączanych do działań wojennych tuż po ataku na Pearl Habor. Obydwa produkty o odmiennym przeznaczeniu łączył namysł nad ludzkim ciałem oraz materiał, z jakiego zostały wykonane - lekka sklejka. Do projektowania kolejnych przedmiotów Eamesowie wykorzystywali też tworzywa sztuczne: poliamid, włókno szklane, siatkę drucianą i aluminium. Łącząc je z materiałami naturalnego pochodzenia, jak choćby ze skórzaną tapicerką, tworzyli też inne siedziska: fotele i sofy. Najsłynniejszym spośród nich pozostanie być może szezlong wykonany dla wspólnego przyjaciela Ray i Charlesa, hollywoodzkiego reżysera Billy’ego Wildera[6] (1968). Kandydatów do najważniejszego w hierarchii mebla jest zresztą więcej - film Eames: The Architect and the Painter reż. Jason Cohn, Bill Jersey (2011) rozpoczyna ujęcie pustego fotela Lounge Chair.

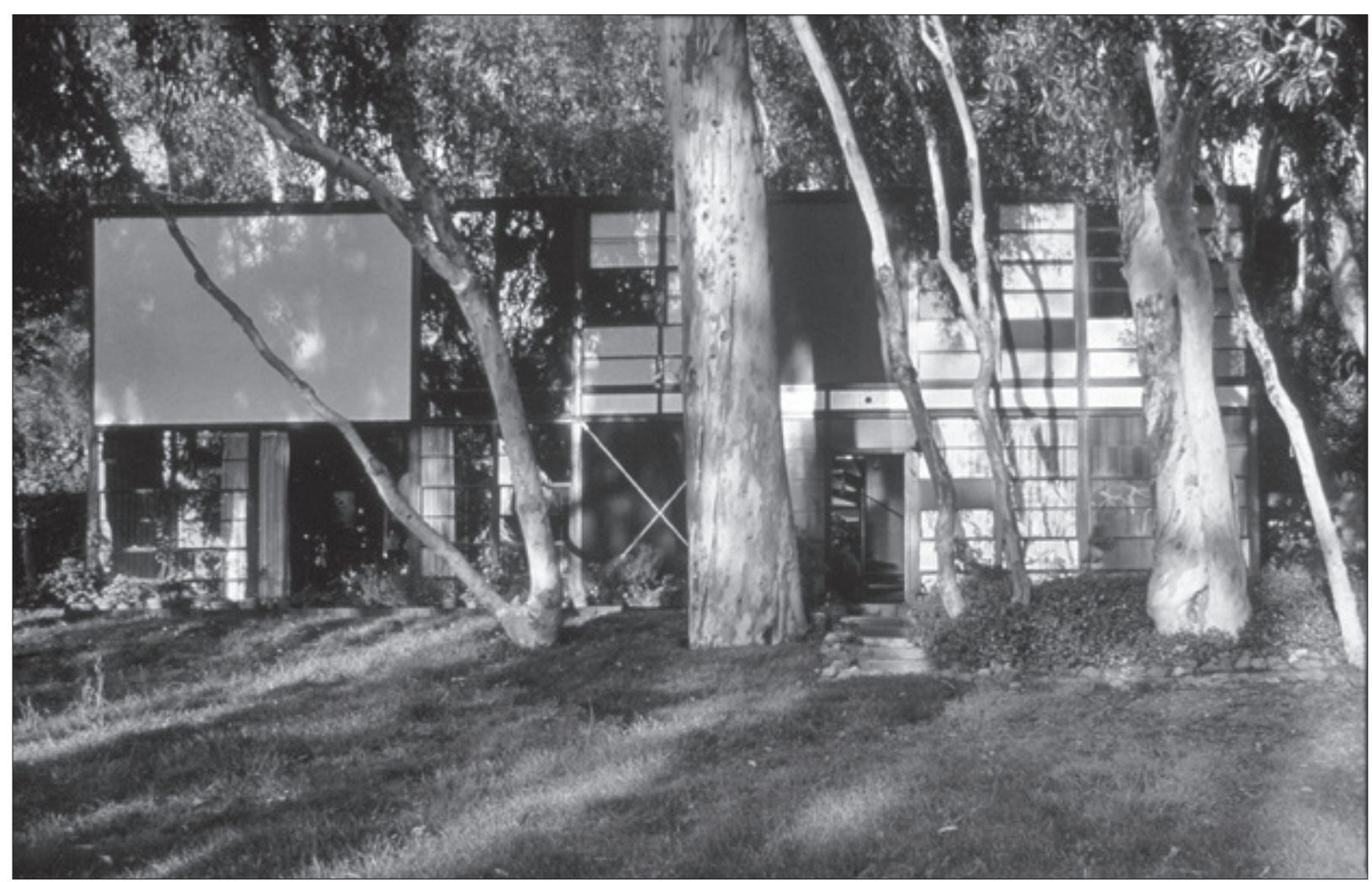

Il. 2. Case Study House \#8, dom Eamesów w Pacific Palisades w Los Angeles

(c) Eames Office, LLC

Do elementów wyposażenia wnętrz na pewnym etapie dołączył projekt ich własnego domu w Pacific Palisades w Los Angeles[7], znany

brook Academy of Art, na konkurs Organic Design in Home Furnishing z 1940 roku, który rozstrzygnięto latem 1941 roku. Podaję za: The World of Charles and Ray Eames...

[6] Odpowiadali też za powietrzne sekwencje do jednego z jego filmów, poświęconego historii Charlesa Lindbergha, który jako pierwszy bez śródlądowań przeleciał ze Stanów Zjednoczonych do Europy: The Spirit of St. Louis (1956).

[7] Wprowadzili się tam w grudniu 1949 roku. 
pod nazwą Case Study House \#8, z zewnątrz przypominający bryłę monumentalizującą obrazy Pieta Mondriana, w środku zaś modernistyczny gabinet osobliwości. Miejscem, w którym stworzyli warsztat pracy, było jednak Eames Office przy 901 Washington Boulevard[8]. Tam wraz z zatrudnionymi współpracownikami realizowano projekty dla klienta państwowego oraz firm takich jak IBM, Westinghouse, Polaroid, Pan American Airways i Boeing.

Międzynarodowa recepcja interdyscyplinarnych osiągnięć Ray i Charlesa Eamesów z obszaru designu, architektury, filmu i multimedialnych ekspozycji waha się od zachwytu nad kreacją totalną, która najczęściej obejmuje też fenomen ich partnerskiego związku, do widzenia tego życiowego projektu w ścisłym powiązaniu z polityką i ekonomią Stanów Zjednoczonych na przełomie trzech kolejnych dekad: od lat pięćdziesiątych do siedemdziesiątych. Niezwykle rzadko Eamesowie stają się przedmiotem zainteresowania historyków kina. Jedyna monografia książkowa poświęcona ich osiągnięciom filmowym napisana została przez architekta i opublikowana w linii wydawniczej dedykowanej architekturze[9]. Przyczyna leży najpewniej w samych Eamesach i ich podejściu do kina właśnie jako narzędzia do tworzenia nowoczesnej architektury informacji.

„Nie-filmy”

W niniejszym artykule skupię się wyłącznie na specyfice wybranych filmów, które tworzyli, i na przestrzeniach, w jakich były wyświetlane. Istotne jest już pierwszeństwo realizacji filmów przed użyciem ich jako karty przetargowej w relacjach z klientami i potrzebami rynkowymi. Pierwsze filmy, które powstały na początku lat pięćdziesiątych, zainicjowały długofalowy ciąg fascynacji na pozór niepoważnymi aspektami rzeczywistości, bardzo często powiązanymi z zabawą, zabawkami i maskami. Widać w nich echo doświadczeń cyrkowych i karnawałowych. Należałyby do nich na pewno Parade or Here They Come Down the Street (1952), Toccata for Toy Trains (1957), Day of the Dead (1957), Tops (1969)[10], chociaż wskazana tendencja w różnym stopniu manifestowała się też $\mathrm{w}$ innych produkcjach. Podejście modelowe za każdym razem powinno uwzględniać równoległość tworzonych produktów i wzajemne zachodzenie na siebie różnych obszarów życia zawodowego. Za wyjątkowo ważne uważam więc podkreślenie tożsamości widzenia projektowego. Eamesowie w filmie widzieli dokładnie te same elementy, które powszechnie uważane są za cechy konstytutywne

[8] P. Kirkham, Charles and Ray Eames. Designers of the Twentieth Century, Cambridge, Mass., London 1998, s. 88-89.

[9] Warto przypomnieć też istotne z punktu rozumienia spuścizny Eamesów pierwsze usystematyzowane podejście do ich produkcji filmowych, które już w 1970 na łamach „Film Quaterly” zaproponował Paul Schrader. Zob. P. Schrader, Poetry of ideas. The films of Charles Eames, „Film Quarterly” 1970, vol. 23, no. 3, s. 2-14.

[10] Nie wstydził się swojej dziecięcości i zabawy, jaką czerpał $\mathrm{z}$ animacji zabawek - robiąc filmy, szukał dla nich nowego przeznaczenia. Wypowiedź współpracownika z Eames Office i komentarz do filmu Eames: The Architect and the Painter, reż. Jason Cohn, Bill Jersey (2011). 
designu: strukturę, materiał i cel[11]. W odpowiedzi na pytanie, w jakim celu zrobili film inicjujący współpracę z IBM (International Business Machine) A Communication Primer (1953), Charles Eames w 1975 roku odpowiadał, „żeby zaprezentować architektom teorię informacji. Jak sprawnie i skutecznie posługiwać się informacjami praktycznie każdego rodzaju" [12]. Oczywiście nie była to jedyna grupa zawodowa, jaką byli zainteresowani, a za zleceniem szły też finanse. Eamesowie, podejmując się działań komercyjnych, wychodzili jednak naprzeciw potrzebie łączenia różnych gałęzi wiedzy i poszukiwania dla nich wygodnego języka przekazu, który pozwoliłby na sformułowanie komunikatu dostępnego dla wszystkich. Można zresztą użyć też spojrzenia panfilmowego, wychodząc z założenia, że właśnie filmy, a właściwie audiowizualne platformy, spajały wszystkie inne obszary kreacji. Argumentem za takim podejściem byłaby przyczyna, dla której pojawili się w przestrzeni targów Expo w 1958 roku w Brukseli: materiał filmowy przygotowany dla Hermanna Millera prezentował meble ich autorstwa, przede wszystkim krzesła, które jednocześnie udostępnione zostały zwiedzającym nie jako część amerykańskiej ekspozycji, ale element praktycznego wyposażenia pawilonu. Ray i Charles Eamesowie odpowiedzialni byli za pomysł, produkcję i reżyserię ponad stu tytułów filmowych.

Eric Schuldenfrei w odniesieniu do filmów Eamesów kilkakrotnie używa terminu „eseje wizualne”. Jednocześnie stosunkowo dużo miejsca poświęca środkom perswazji[13]. Pisze więc ostatecznie o specyficznej odmianie propagandowego eseju wizualnego, werbującego uwagę widza na rzecz nauki. Podkreślam tę odmienność gatunku, ponieważ esej z założenia nie jest nacechowany funkcją impresywną. Etymologiczne zaplecze samego pojęcia próby (z języka francuskiego essai) skupia się na ważeniu słów, poszukiwaniu prowadzonym często bez wyraźnego i ostatecznego zakończenia[14]. Zdaniem Tomasza Kłysa „wolnościowe" podejście do struktury zakłada brak uprzedmiotowienia wszelkich „dyskursów” i postaw postaci, ich wypowiedzi, dialogów, działań podporządkowanych jedynej ramie, jaką jest logika przeka$\mathrm{zu}[15]$. Ale już Margarete Wach zauważa, że esej filmowy wprowadza również fikcyjne i dokumentalne materiały archiwalne, które argumentacyjnie wspierane są niekiedy też głosem narratora[16]. I w tej wykładni jesteśmy już blisko Eamesów, którym zresztą najbliższe chyba było określenie „nie-filmów”: „(t)o nie są filmy eksperymentalne, właściwie

[11] Taka definicja organicznego designu sformułowana została przez Eliota Noyesa w konkursie Home Furnishings w 1941 roku. Podaję za: E. Schuldenfrei, The Films of Charles and Ray Eames: A universal sense of expectation, Routledge 2015, s. 8. Definicja taka przytoczona została też przez Charlesa Eamesa w filmie Design Q \& A (1972) reż. Charles i Ray Eames.

[12] Podaję za E. Schuldenfrei, op.cit., s. 24.

[13] Ibidem, s. 146.
[14] N. Alter, Translating the essay into film and installation, "Journal of Visual Culture” 2007, nr 6 (1), s. 50, <https://doi.org/10.1177/14 $70-412907075068>$, dostęp: 21.12.2019.

[15] Por. T. Kłys, Film fikcji i jego dominanty, Warszawa 1999, s. 155-158.

[16] M. Wach, Esej jako gatunek filmowy Nowych Fal: Kluge - Zanussi - Makavejev, tłum. M. Kryś, [w:] W poszukiwaniu polskiej nowej fali, red. A. Gwóźdź, M. Wach, Warszawa, Kraków 2017, s. 255-279. 
to nie są filmy (they're not really films). Są tylko próbą przekazania jakiejś idei. Używamy tylko narzędzia, które ktoś inny rozwija”[17].

Poszczególne realizacje wypełniają powtarzalne składowe: "migające” sekwencje statycznych zdjęć, muzyka Elmera Bernsteina, kreska Glena Flecka w partiach animowanych, wydająca się nie mieć końca biblioteka zdjęć, komentarz narratora, któremu głosu najczęściej użyczał sam Charles. Stałą techniką, jaką wykorzystywano w Eames Office do wizualizacji problemu, tuż obok rysunków, było budowanie atrap, makiet imitujących w mniejszej skali rzeczywiste przedmioty czy też cały układ przestrzenny. O rytmie narracji decydował charakterystyczny dla Eamesów czynnik szybkości montażu zdjęć. Przykładowo w filmie The House: After Five Years of Living (1955) trwanie pojedynczego ujęcia nie przekracza jednej sekundy. Dzięki tej właśnie technice Eamesowie dostali w 1960 roku nagrodę specjalną Emmy za wkład w realizację programu Fabulous fifties [Cudowne lata 50.] dla telewizji CBS[18]. Naprzemienny, szybki montaż maksymalizował ilość informacji możliwych do przekazania w określonej ramie czasowej i stał się znakiem rozpoznawczym Eamesów[19]. Odwoływali się w tej praktyce do doświadczeń kina awangardowego, które w ich realizacjach znalazło zdolnego popularyzatora. Ta sama technika, ze względu na ofertę dostępu w pawilonach wystawienniczych, salach wykładowych, muzeach czy telewizji, skutecznie wyprzedzała też epokę ugruntowaną przez późniejszą stację muzyczną MTV - czy szerzej technikę wideoklipu.

Zdaniem autora The Films of Charles and Ray Eames: A Universal Sense of Expectation, ze względu na chęć użycia stopklatek, materiałów zdjęciowych Eamesom bliżej jest do historii fotografii niż do historii filmu. Dzięki zastosowaniu zdjęć wyraźniej mogli wyeksponować zawartość wizualną[20]. W rzeczywistości jednak punkt newralgiczny w decyzjach montażowych filmów linearnych, i późniejszych „wystawowych", stanowiło zetknięcie materiałów statycznych i dynamicznych, fotosów i fragmentów filmowych, w późniejszym czasie też napięcie między specyfiką samej projekcji a jej zawartością semantyczną.

$\mathrm{Z}$ wyjątkiem ciekawego eksperymentu dydaktycznego, o którym piszę w części inicjującej eksplikację projektów wieloekranowych, Eamesowie zasadniczo współpracowali z instytucjami, których priorytetem nie była edukacja. Ta należała do infrastruktury szkół i uniwersytetów, kiedy oni nie chcieli dotrzeć do elity, ale do mas[21]. Film był dla nich narzędziem demokratyzacji wiedzy[22]. Używali filmu

[17] An Eames Anthology... s. 288.

[18] Oto szczegółowe wyliczenie tych sekwencji, za które odpowiadali: Music Sequence, Dead Sequence, De Gaulle, Gift from the Sea, The Comics, Where Did You Go-Out?. Podaję za: An Eames Anthology..., S. 296.
[19] Już w latach siedemdziesiątych na tę specyfikę przekazu Eamesów zwrócił uwagę Paul Schrader. Por. P. Schrader, op.cit.

[20] E. Schuldenfrei, op.cit., s. 216.

[21] Chociaż to do elit właśnie skierowane było wykładowe tournée, które zorganizowało Charlesowi IBM w 1975 roku.

[22] E. Schuldenfrei, op.cit., s. 98. 
do organizacji informacji w strukturę narracyjną[23]. Właściwie byli dydaktykami amatorami, którzy na dodatek chcieli z innymi dzielić się praktycznymi rezultatami swoich poszukiwań[24]. Oferowali narzędzia filmowe tym dziedzinom nauki, które były pozbawione szerszej reprezentacji[25].

Dla wizualizacji powyższej diagnozy przywołam trzy wybrane filmy zrealizowane na przestrzeni trzech różnych dekad. Wspomniany już wcześniej A Communication Primer (1953) [Elementarz komunikacji] przygotowany został na ekspozycję w kalifornijskim muzeum, ale jednocześnie zapoczątkował długofalową współpracę z firmą IBM[26]. Film rozpoczyna słownikowa definicja komunikacji, odczytywana przez wewnątrzfilmowego narratora-przewodnika, scalającego prezentowany materiał złożony z infografik, diagramów, schematów, zdjęć, rycin, grafik i filmowego materiału dokumentalnego. Film ma wyraźnie forsowaną tezę: prymarne mechanizmy komunikacyjne, właściwe ludzkiej naturze, warunkują też technologiczne przedłużenia zmysłów, czyli przekaźniki. Obieg informacji możliwy jest między ludzkimi i nieludzkimi aktorami sieci komunikacyjnej. Immanentną cechą tej i kolejnych realizacji, stanowiących ciekawy przykład syntezy nauki i technologii[27], jest tendencja „uczłowieczająca” maszyny[28]. Poprzez tworzenie analogii z procesami kierującymi „maszynami ludzkimi” oswajane są obszary technologicznie obce czy nawet inwazyjne dla środowiska człowieka. Ten wymiar interpretacyjny filmu ściśle przylegał do konsekwentnie prowadzonej od pierwszej połowy lat pięćdziesiątych zmiany społecznego wizerunku firmy IBM. Mimo odrębnej podmiotowości właśnie ekspansja tego konkretnego koncernu ściśle współistnieje z polityką państwa, dla którego kluczowy w tamtym czasie był jeszcze temat bomby atomowej i „gwiezdnych wojen”. Charles Eames, obok kilku innych wizjonerów designu, takich jak Eliot Noyes, Paul Rand, George Nelson czy Edgar Kaufmann Jr., wchodził w skład zespołu konsultanckiego odpowiadającego za nowoczesny interfejs marki IBM[29]. Powojenne komunikaty reklamowe przeciwstawiały ofertę firmy zagrożeniu wynikającemu z eksperymentów z użyciem energii jądrowej. Nowy sztab doradców nie chciał już straszyć Amerykanów, ale starał się przemysł komputerowy wpisać w społeczno-kulturową transformację: przekonywał do wizerunku nowoczesnego producenta idei[30]. Eamesowie dzięki swoim filmom odegrali kluczową rolę w przekierowaniu tego

[23] Ibidem, s. 109.

[24] Ibidem.

[25] Ibidem, s. 102.

[26] Filmy, które powstały w celu zbudowania zaufania do technologii IBM: The Information Machine, 1958; Introduction to Feedback (1960), IBM Mathematics Peep Show (1961), House of Science (1962), Think (1964), IBM Puppet Shows (1965), (Sherlock Holmes in 'The Singular Case of the Plural Green Mustache' i Computer Day at Midvale), A Computer Glossary (1967), IBM Museum (1967), A Computer Glossary or,
Comming to Terms with the Data Processing Machine (1968).

[27] E. Schuldenfrei, op.cit., s. 2.

[28] Zob. J. Harwood, The Interface IBM and the Transformation of Corporate Design 1945-1976, Minneapolis, London 2011.

[29] Podaję za: ibidem, s. 3.

[30] E. Schuldenfrei, op.cit., s. 153 i nast. Temu zagadnieniu poświęcona jest też przywołana powyżej książka Johna Harwooda. 
wizerunku w stronę korporacji odpowiedzialnej społecznie, niosącej ludziom nowe formy wiedzy.

The Powers of Ten (1968) to z jednej strony dojrzałe, być może najciekawsze stadium współpracy z IBM, z drugiej ciekawy przykład intuicji posthumanistycznej: porzucenie spojrzenia ludzkiego na rzecz perspektywy kosmicznej. Punkt wyjścia filmu to obraz statystycznej pary, młodego amerykańskiego małżeństwa, spędzającego leniwe niedzielne popołudnie w parku. W reżyserii tego migawkowego pikniku łatwo rozpoznać „rękę” Ray: ten sam zmysł estetycznej interwencji widoczny był już w wystroju wnętrz w filmie The House... To jedynie punkt odniesienia potrzebny do przedstawienia na ekranie dystansu dzielącego człowieka od różnych kosmicznych wielkości, gdzie szybkość montażu poszczególnych obrazów analogiczna jest do tempa zwiększania się dystansu od sielankowej sceny w parku. Prędkość pokonywania dystansu fizycznego odpowiada szybkości zmieniających się ujęć, a ta odpowiada szybkości, z jaką dzisiaj bombardowani jesteśmy kaskadą informacji, z którymi nie zawsze wiemy, co zrobić. Stanu niepewności wynikającego z przeładowania danymi doświadczamy dzisiaj, doświadczał go też widz filmów Eamesów. Skok cywilizacyjny, jaki dokonał się na przestrzeni ostatnich dekad, miałby więc swoją zapowiedź w „stroboskopowej” umysłowości architekta i designerki, których kompetencja zagarniała jeszcze kolejny teren: projektowanie przyszłego modelu percepcji odpornej na niekończący się strumień nowych informacji. Myśląc o Powers of Ten, jednego czynnika nie powinniśmy jeszcze tracić $\mathrm{z}$ pola widzenia: nieubłaganego zbliżania się do daty lądowania na Księżycu. Napięcie wynikające z oczekiwania na nowe formy kontaktu $\mathrm{z}$ „kosmiczną pustką” wcale zresztą nie zelżało wraz z telewizyjną transmisją z 20 lipca 1969 roku. Kolejna dekada wypełniona była nowymi misjami mającymi na celu pokonanie niemożliwych wcześniej odległości, związanych z przekroczeniem ram Układu Słonecznego. Po latach owo napięcie i oczekiwanie widoczne jest również w tej krótkiej formie filmowej z 1968 roku. Nowością w stosunku do często wykorzystywanego głosu Charlesa w roli narratora filmu było zastąpienie go autorytetem eksperckim Philipa Morrisona, fizyka z MIT (Massachusetts Institute of Technology).

W Powers of ten Eamesowie podzielili się ze statystycznym Amerykaninem inspirującą wiedzą wyrastającą z rozpoznania technologicznego (i dzięki niemu możliwą do wizualizacji), jednak w ostatecznym rozrachunku odpowiedzialną za nowy kapitał ezoteryczny. Podniosły i uroczysty ton zagwarantowany autorytetem fizyka z MIT wspiera optymistyczny efekt uboczny: przekonanie o możliwości przekroczenia dotychczasowych ograniczeń wiedzy i kontroli[31]. O czym przekonująco pisał już James Weems, główną ofiarą tego rewelatorskiego procesu poznania jest zniknięcie ludzkiego ciała - ono jako miara wszystkich

[31] J. Weems, Vision at California Scale, Charles and Ray Eames, systems thinking and the diminishing status of the human body after World War II, [w:] Where
Minds and Matters Meet. Technology and California in the West, red. V. Janssen, Berkeley, CA, 2012, s. 255. 
rzeczy znika zarówno z filmu Eamesów, jak i powojennej kultury. Ta diagnoza może być kluczowa dla zrozumienia twórczości Eamesów w ogóle: bezcielesne, nieorganiczne spojrzenie, wizualność, dla której miarą przestaje być ciało człowieka. Być może Powers of Ten inkorporuje właśnie spojrzenie pozbawione ciała i jest to jeszcze bardziej niepokojące niż charakterystyczna dla Eamesów szybkość następujących po sobie obrazów. Genezę dla takiego stanu rzeczy Weems widzi w dwóch czynnikach: Kalifornii jako przestrzeni o nieskończonych możliwościach (czego prostą konsekwencją byłaby nieustannie zabiegająca o własną hegemonię Dolina Krzemowa), a w sensie szerszym w specyfice samych Stanów Zjednoczonych spełniających w relacji do Starego Kontynentu funkcję metonimii konkretnej, ale nieograniczonej przestrzeni geograficznej[32]. Tymi samymi kwestiami co filmy Eamesów przesiąknięta była wówczas cała amerykańska kultura. Widownia próbowała zrozumieć, jakie jest jej miejsce w nowym, wizualnym porządku świata, który dynamicznie zmieniał się pod wpływem odkryć naukowych i wdrażanych wynalazków technologicznych. Właśnie ten czynnik zdecydował o ogromnej, a nie tylko programowo sterowanej popularności filmu. Eamesowie uczestniczyli w wychowaniu kolejnego pokolenia Amerykanów nie tylko poprzez meblowanie fizycznego środowiska ich życia, ale i poprzez dostarczenie oferty edukacyjnej, narzędzi do bycia częścią nowego świata.

$S X-70$ (1972) to pozornie reklama konkretnego produktu, nowego modelu aparatu fotograficznego firmy Polaroid. W rzeczywistości widz dostaje swojego rodzaju pakiet humanistyczno-instruktażowy. Niespełna dziesięciominutowy film najpierw spełnia wymogi materiału poglądowego: kto? gdzie? w jakich sytuacjach? używa takiego właśnie sprzętu. Spektrum jest rozległe: od uwieczniania wspólnych, ulotnych chwil z bliskimi pod różnymi szerokościami geograficznymi, a może po prostu w środowisku wieloetnicznej społeczności amerykańskiej, przez różne formy spędzania czasu wolnego we wnętrzach i w plenerze, po rejestrację sytuacji prozaicznych i zabawnych. Akcentowane są różne możliwości użycia niezwykłego aparatu do zdjęć, który jest właściwie miniaturowym, przenośnym wyzwalaczem i fotograficzną ciemnią zamkniętą w jednej skrzynce. Film pełni funkcję informacyjną już w tym sensie, że proponuje mniej i bardziej oczywiste zastosowania aparatu: jako dokumentatora prywatnych i oficjalnych kolekcji czy jako przyczynek do działań protofilmowych, zainicjowanych przez serię zdjęć wykonanych jedno po drugim, które, ustawione obok siebie, dadzą efekt animacji. Sama możliwość wykonania serii zdjęć była związana z szybkością migawki, niedostępną w dotychczasowych modelach Polaroida. Ale to tylko warstwa wierzchnia. Stopniowo funkcja perswazyjna ustępuje potrzebie wejścia „w głąb”. Zastosowanie infografiki pozwala na szczegółową obserwację procesu mechaniczno-optycznego. Film reklamowy staje się filmem popularnonaukowym. Każdy poten-

[32] Por. ibidem, s. 258-263. 
cjalny konsument awansuje do roli początkującego adepta nowoczesnej wiedzy tajemnej. Nie satysfakcjonuje go fasada przedmiotu. Nie przyjmując gotowego efektu, chce wiedzieć więcej. Jak dziecko zadaje pytania podstawowe o naturę samego procesu. Co ważne, prezentację powierzchni aparatu fotograficznego, jak i niewidocznego na co dzień wnętrza charakteryzuje podejście estetyzujące. W procesie zdejmowania kolejnych warstw film idzie jeszcze dalej, pokazując naukowo sterylny proces produkcji poszczególnych mikroelementów niezbędnych do skompletowania całości. Aparat - nadal oczywiście przedmiot konsumpcyjny - staje się medium sprzęgającym nasze oko, mózg i rękę w jedno. Fenomen uchwytny dla każdego to otrzymywane po 14 sekundach zdjęcie, natychmiastowy, materialny dowód naszej egzystencji, który zbliża nas do błyskawicznego procesu zachodzącego „tu i teraz”. Odłącza nas od absorbującego zaangażowania czasowego czy konieczności korzystania z pośredników, takich jak profesjonalne atelier fotograficzne. Zresztą granica między amatorem a ekspertem skutecznie się zaciera. Nadal jesteśmy konsumentami, ale dzięki filmowi zbliżamy się do tajemnicy optyki i mechaniki. Co ciekawe, wymiar artystyczny jest właściwie skutkiem ubocznym innych, docelowo pragmatycznych działań. Sam kwadratowy format zdjęć odwoływał się do możliwości profesjonalnych aparatów wielkoformatowych[33]. Artystą zostaje się przy okazji dobrze zorganizowanego, również od strony instrumentarium, czasu wolnego. Wątek negowania wartości sztuki jako autoekspresji jest pewną stałą tendencją charakteryzującą działania Eamesów: od pewnego momentu formułują subtelną krytykę artystów poprzez sztukę chcących wyrażać samych siebie. Ray i Charles żywią przekonanie, że sztuka powinna być platformą do badań i poszerzać istniejące obszary wiedzy[34]. Sztuka musi mieć zawsze jakiś wymierny cel. Ma komunikować idee w przejrzysty sposób i integrować różne pola ludzkiej aktywności[35]. Warto podkreślić, że podobnie funkcję sztuki definiowali artyści renesansowi. Leonardo da Vinci swoje obrazy uważał za teksty naukowe, które scalały jego horyzont wiedzy $\mathrm{z}$ rozmaitych dziedzin.

Od pokazu slajdów do wielozmysłowego kanału:

Glimpses of the U.S.A.
W rzędzie ważnych doświadczeń zawodowych tuż obok pierwszych filmów już w roku 1953 pojawia się ważny eksperyment dydaktyczny. Doszło do niego w wyniku współpracy z Georgem Nelsonem i Alexandrem Girardem, którym zaoferowano zorganizowanie kursu na dwóch uczelniach: University of Georgia i UCLA. Był to metapoziom nauczania, poszukiwania nowych metod aktywizujących uwage studentów i odbiorców w ogóle. To, co udało się opracować na użytek wspomnianego kursu można śmiało nazwać pierwszą publiczną prezentacją z wykorzystaniem technik multimedialnych. Projekt pod
[33] Współcześnie do tego kanonicznego formatu spopularyzowanego przez Polaroid odwołuje się medium społecznościowe Instagram.
[34] E. Schuldenfrei, op.cit., s. 130.

[35] Ibidem, s. 5. 
nazwą A Rough Sketch for a Sample Lesson for a Hypothetical Course zakładał nie tylko przedstawienie na ekranie trzech obrazów jednocześnie, ale i fizyczny udział prezentera-wykładowcy, korzystającego $\mathrm{w}$ miarę potrzeby $\mathrm{z}$ tablicy, fakultatywnie zastępowanej wydrukiem materiałów wizualnych. W wersji modelowej przez system wentylacyjny miały być jeszcze rozprowadzane zapachy w następstwie sukcesywnie pobudzanych receptorów[36]. Jak podaje Pat Kirkham partie zrealizowanego kursu, za które bezpośrednio odpowiedzialne było małżeństwo Eamesów, to Communications Process i Communications Methods[37]. Jej „linearnym rozwinięciem” byłby zrealizowany jeszcze w tym samym roku A Communication Primer, o którym pisałam wcześniej.

Po wystawie światowej w Brukseli w 1958 roku Eamesowie otrzymali propozycję realizacji filmu oraz zaproszeni zostali do współpracy nad projektem pawilonu wystawienniczego przeznaczonego na niecodzienne, w dziejach powojennego świata, wydarzenie historyczne: spotkanie dwóch przeciwległych mocarstw połączone z wzajemną prezentacją osiągniętego statusu materialnego i symbolizujących go przedmiotów prestiżu. Eamesowie przygotowywali się do wystawy moskiewskiej skupionej na autopromocji Amerykanów, która trwała od 25 lipca do 4 września[38]. Poprzedzała ją wystawa nowojorska $\mathrm{z}$ analogiczną prezentacją strony radzieckiej (od 30 czerwca do 10 sierpnia). Opis warunków projekcyjnych i nadrzędnego środowiska ekspozycji, w którym wyświetlano zrealizowany przez Eamesów Glimpses of the U.S.A [U.S.A. $w$ mgnieniu oka] jest konieczny do zrozumienia historycznego wymiaru tego wydarzenia. Nie chodzi więc tu wyłącznie o kształt bryły pawilonu, tak zwanej kopuły geodezyjnej, wielościanu odwzorowującego kształt kuli, za który odpowiedzialny był architekt i wizjoner R. Buckminster Fuller[39]. Choć już sama konstrukcja budowli umożliwiała zainstalowanie siedmiu samonośnych ekranów, każdy o wymiarach 6 x 10 m, na których wyświetlano w trybie symultanicznym film Eamesów nakręcony na $35 \mathrm{~mm}$ taśmie filmowej. Podkreślenia wymagają też okoliczności towarzyszące. Po pierwsze wystawa, zorganizowana w moskiewskim parku Sokolniki, była efektem chwilowego ocieplenia stosunków między mocarstwami w konsekwencji śmierci Stalina (1953), referatu wygłoszonego na XX Zjeździe Radzieckiej Partii Komunistycznej (1956) i porozumienia o wymianie kulturalnej podpisanego w 1958 roku. Do spotkania Nikity Chruszczowa, premiera ZSRR i Pierwszego Sekretarza Partii z wiceprezydentem Stanów Zjednoczonych Richardem Nixonem doszło na tle ekspozycji amerykańskiej kuchni zaprojektowanej przez

[36] E.L. Altimus, Out of Many, One: Glimpses of the USA by Charles and Ray Eames, The Family of Man by Edward Steichen, and universal thought in cold war propaganda, (2012). LSU Master's Theses. 2892. $<$ https://digitalcommons.lsu.edu/gradschool_theses/2892>, dostęp: 21.12.2019.
[37] P. Kirkham, Charles and Ray Eames: Designers of the twentieth century, Cambridge, Mass., 1995, s. 320. [38] L. Naessens, Communicating America: Moscow, 1959, [w:] The World of Charles..., s. 268.

[39] Buckminster konstrukcje tego rodzaju spopularyzował już w latach 40. XX wieku. Zob. między innymi J. Keats, You belong to the Universe. Buckminster Fuller and the Future, Oxford 2016. 
Jacka Maseya, koordynatora projektów w amerykańskiej agencji informacji (USIA). Spotkanie przeszło więc do historii pod nazwą „debaty kuchennej”[40]. Masey zdecydował też o włączeniu do wystawy pokazu mody, akcentującego amerykańską codzienność, oraz krótkiego przeglądu współczesnej sztuki amerykańskiej (między innymi prac malarzy Jacksona Pollocka czy rzeźbiarzy takich jak Theodor Roszak, Jose de Creeft czy Alexander Calder)[41]. Ten wachlarz rozmaitości uzupełniał jeszcze najnowszy model komputera firmy IBM (RAMAC 305), aparat fotograficzny Polaroid, ale i wyposażenie typowego amerykańskiego domu, które obejmowało zmywarkę, sokowirówkę, mikrofalówkę. Listę sprzętów zamykała prezentacja dwudziestu dwóch amerykańskich samochodów[42]. Zarówno IBM, jak i Polaroid należeli do klientów Eames Office.

W ramach całościowej ekspozycji rolę sprawdzonego już wcześniej żelaznego punktu programu spełniła wystawa fotograficzna Edwarda Steichena The Family of Man (Rodzina człowiecza). Była ona wyrazem powojennych zainteresowań kondycją człowieka w skali globalnej i podsumowaniem dotychczasowych działań w obszarze fotografii społecznej. W przeciwieństwie do oryginalnego budynku MOMA[43], w którym zaprezentowana została cztery lata wcześniej, teraz postanowiono pokazać ją w przestrzeni otwartej, z dostępem do naturalnego źródła światła, pod „zadaszeniem” stworzonym z plastikowych parasoli zaprojektowanych przez George'a Nelsona[44]. The Family of Man objęła swoją kuratorską narracją 503 zdjęcia z 68 krajów. Stałe miejsce w dwudziestowiecznej historii fotografii wystawa Steichena zawdzięczała przede wszystkim wejściu w obieg międzynarodowy. W perspektywie długofalowej unieśmiertelniona została, choć raczej w optyce krytycznej, przez Rolanda Barthes'a w Mitologiach (1957) i przez Susan Sontag w O fotografii (1977). O jak najszerszy zasięg zadbała Amerykańska Agencja Informacyjna (USIA), organizując objazdowe tournée w 91 miastach w 38 krajach w latach 1955-1962[45]. W tym sensie obecność wystawy w Moskwie można rozumieć jako niezależny pochód projektu, do którego film Eamesów tylko dołączono.

[40] Podobno była to zresztą ta część mieszkania, do której Chruszczow miał wyjątkową słabość. Podaję za E. Schuldenfrei, op.cit., s. 87.

[41] Por. też: <https://www.nytimes.com/2016/03/22/ arts/design/jack-masey-whose-exhibitions-showed-american-culture-to-world-dies-at-91.html>, dostęp: 10.04.2020

[42] Dla porównania o miesiąc wcześniejsza wystawa radziecka, zlokalizowana w New York City Coliseum, miała służyć tym samym celom „człowiekowi radzieckiemu”, czyli prezentacji utopijnej wersji samego siebie. Ten, nie mogąc pochwalić się ogólnodostępnym konsumeryzmem, nacisk kładł na przemysł ciężki, obok sprzętu kolejowego, militarnego prezentując też model sztucznego satelity Sputnik. Por. też A.A. Jopp, The American National Exhibition in Moscow 1959: Purpose and Politics. <http://bestamericanart. blogspot.com/2011/05/the-american-national-exhibition-in.html>, dostęp: 10.04.2020.

[43] Wystawa w MOMA w Nowym Jorku była dostępna od 24 stycznia do 8 maja 1955.

[44] To on był „mózgiem wystawy”, który zaprosił do współpracy Eamesów. Podaję za: L. Naessens, op.cit., s. 268.

[45] <https://fkmagazine.lv/2018/o7/o2/the-family-of-man-the-photography-exhibition-that-everybody-loves-to-hate/>, dostęp: 1.03.2020. 
Zdaniem Elisabeth Altimus centralny punkt wystawy Steichena stanowił przekaz ery atomowej i wszystkich zagrożeń i możliwości, jakie za sobą pociągała[46]. Stały za nią ambicje totalne, globalne. Sedno przekazu, oparte na fałszywych, ideologicznych przesłankach, stanowiło przekonanie, że mimo różnorodności kulturowej jest jeden człowiek i jeden świat. Takie założenie pomijało wykluczenie spowodowane czynnikami rynkowymi i edukacyjnymi. Historycy wskazują na tożsamość źródeł, z których korzystał projekt Steichena i Eamesów [47]. Główną skarbnicą wizualną były zbiory agencji Magnum, która powstała właśnie w geście uniezależnienia się od czasopism, w efekcie uświadomienia sobie opiniotwórczej siły medium fotografii. Niezwykle ważną właściwością tej instytucji była wielonarodowość jej członków, z których duża część przybyła do Stanów Zjednoczonych w latach trzydziestych i czterdziestych XX wieku. Zasadą, z której Magnum zasłynęło, było delegowanie poszczególnych fotografów w różne odległe zakątki świata, co stanowiło zupełnie nowe podejście reporterskie. Celem przyświecającym najsłynniejszej agencji na świecie było stworzenie kroniki całego świata[48]. Projekty omawiane w ramach wystawy moskiewskiej czerpały z tej kroniki według własnego arbitralnego uznania. Dwutorowa reprezentacja Ameryki nie uwzględniała choćby już takiego jej wizerunku, jaki znalazł się w albumie Roberta Franka Z 1959 roku, The Americans, Ameryki przedmieść i suburbiów, gdzie ławka w parku nie sąsiaduje z człowiekiem dbającym o aktywność fizyczną, ale staje się tymczasowym schronieniem dla bezdomnego[49].

Jakie były warunki projekcyjne filmu Eamesów, Glimpses of the U.S.A? Sposób rozmieszczenia siedmiu ekranów - czterech w górnym rzędzie i trzech w dolnym - dawał możliwość użycia ich wszystkich jednocześnie, ale też wybiórczo[50]. Płaszczyzna projekcyjna przypominała rozłożony model figury przestrzennej albo ułożone obok siebie kawałki układanki, nie zawsze dające się złożyć w całość, zestaw zdjęć podobnych, choć nie identycznych obiektów, zgromadzonych w nadrzędnym albumie według klucza tematycznego (łącznie użyto 2200 zdjęć[51] i zaledwie kilku fragmentów filmowych). Efekt tytułowych migawek zagwarantowany został też na poziomie rytmu montażu: ekrany, a właściwie świetlne, prostokątne plafony o delikatnie zaokrąglonych rogach, sukcesywnie były ożywiane i wyciszane. Dwunastominutowa realizacja, a może po prostu fotopowieść, a ze względu na format raczej fotonowela autorstwa Ray i Charlesa Eamesów, stanowiła impresję na z góry zadany temat. Oferowała coś na podobieństwo kolekcji pocztówek o środowisku życia i samym człowieku, wykazu-

[46] E.L. Altimus, op.cit.

[47] Ibidem.

[48] Zob. między innymi J.G. Morris, Zdobyć zdjęcie, tłum. M. Świerkocki, Warszawa 2007.

[49] Po to zestawienie sięga w swojej książce też Eric Schuldenfrei. Zob. idem, op.cit., s. 90-92.

[50] Rozwiązanie powszechnie dziś stosowane nie tylko na targach Expo, ale i w muzeach sztuki współczesnej oraz w czasie masowych koncertów muzycznych. Por. B. Colomina, Domesticity at War, Cambridge, Mass., London 2007, s. 245-250. [51] Tutaj liczby są różne. Eric Schuldenfrei pisze o 844 zdjęciach, które pochodziły od Charlesa, 427 z gazet. Zob. idem, op.cit., s. 73 . 
jących pewne podobieństwa, ale jednak zawsze w czymś różniących się od siebie. Efekt estetycznie ciekawych kompozycji mógł więc tu być przypadkowy. Tworzyły go na przykład chwytane z lotu ptaka układające się w spirale i lemniskaty nitki autostrad. Widz porzucał percepcję uwikłaną w przyziemne przyzwyczajenia. Sprzyjały temu inicjujące film zdjęcia kosmosu.

Cel, jaki tym razem założyli sobie twórcy, to „dostarczyć wizualną kapsułę złożoności i różnorodności amerykańskiego życia”[52] na przestrzeni tygodnia, jednego $\mathrm{z}$ wielu. Linię narracyjną podpowiadały rytuały śniadań, wychodzenia mężczyzn do pracy, pozostawania żon w domach, wychodzenia dzieci do szkoły, zabaw na szkolnym i domowym podwórku, wieczornych powrotów. W tym rytmie miał się przejrzeć też widz radziecki. Ale schemat powstał jednocześnie z potrzeby wypełnienia go oznakami dobrobytu. Pozwalał też na poruszanie się między przedmieściami, które dawały bezpieczną i spokojną przestrzeń mieszkalną a centrum, które dawało zatrudnienie. Droga pokonywana była w prywatnych samochodach i za pomocą różnych środków komunikacji miejskiej. Miasto dawało możliwość zaprezentowania życia przemysłowego i ruchu ulicznego. Przez Miami Beach, Times Square i Broadway wirtualny turysta dzięki Eamesom trafiał też do Muzeum Sztuki Współczesnej w Nowym Jorku, gdzie podziwiał obrazy Picassa czy Legera. Dzięki Eamesom odwiedzał też cyrk. Obserwował współczesnego Amerykanina uprawiającego golf, jeżdżącego na nartach, grającego w piłkę nożną, baseball, tenis.

Porządek narracyjny był identyczny z logiką cyklu od wschodu do zachodu słońca, naprzemiennym czasem pracy i czasem wolnym. Widz był od początku blisko filmu przyrodniczego, etnograficznego i reklamowego. Koncentrował się na pięknie krajobrazu, lasach, zamieszkujących je zwierzętach, pojedynczych drzewach, skałach, różnorodnie ukształtowanym terenie, również przez człowieka. Zabudowa miejska i infrastruktura dróg nie były tu czymś inwazyjnym, a jedynie przedłużały działania przyrody. Narratorem filmu został Charles Eames, muzykę jak zwykle skomponował Elmer Bernstein. Za element found footage można uznać scenę z filmu Billy’ego Wildera Pół żartem, pół serio (1959), w której Marilyn Monroe zmysłowo mruga do widza. Jak twierdzi Pat Kirkham, jest duża szansa, że w radzieckiej części globu jej obecność na ekranie mogła wiązać się z absolutną anonimowością, dającą się sprowadzić może jedynie do fantazmatu jakiejś/jakiejkolwiek atrakcyjnej blondynki[53].

Materiał zdjęciowy w jakiejś przynajmniej części przygotowany został przez pracowników Eames Office: „Żeby znaleźć potrzebne nam sceny, po prostu wyszliśmy na ulicę"[54]. Poza wspomnianą już agencją Magnum uzupełniały go też zbiory Photo Researches oraz archiwa magazynów „Fortune”, „Holiday”, „Life”, „Look”, „Saturday Evening

[52] R. Eames, M. Neuhart, J. Neuhart, Eames Design: The Work of the Office of Charles and Ray Eames, London 1989, s. 239.
[53] P. Kirkham, op.cit., s. 323.

[54] „We just went out on the street to find our scenes". Zob. An Eames Anthology..., s. 198. 
Post”, „Sports Illustrated”, „Sunset” i „Time” oraz prac pojedynczych fotografów, w tym uznanych już fotografów architektury, takich jak Ferenc Berko, Julius Shulman, Ezra Stoller, Ernst Braun czy George Zimbel[55].

W tym porządku najwyraźniejsze okazywało się nawiązanie do tradycji filmowych „symfonii miejskich”. Tak jak u Ruttmana czy Wiertova miasta budziły się i zasypiały, tak w Glimpses of the U.S.A. rytm życia mieszkańców Ameryki w ciągu hipotetycznego jednego tygodnia wprowadzał „fizjologiczną” chronologię. Z symfoniami miejskim łączy Glimpses... też funkcja użytej muzyki, która ustalała emocjonalną tonację każdej sceny[56].

O czym wspomina już Schuldenfrei, użycie siedmiu ekranów określało pozycję widza jako aktywnego ogniwa projekcji[57], ale generowało też typ nowego, immersywnego doświadczenia. Multiplikacja obrazów rejestrujących podobne, ale nie identyczne obiekty, zwyczajność, przenosiła w sferę podniosłego święta, prozaicznym czynnościom pozwalała urosnąć do rangi międzyludzkiego rytu. Widz miał się w niej zadomowić, poczuć się częścią wspólnoty. Odczytanie krytyczne, które nie traciło z horyzontu uwagi użytych środków perswazji, pozwalało zobaczyć tylko ugrzecznioną i zdezynfekowaną wersję Stanów Zjednoczonych. Nawet jeżeli została ona utkana z różnych źródeł i opatrzona terapeutycznym komentarzem samego Charlesa Eamesa, nadal przekonywała do jednorodnej, monolitycznej wersji człowieczeństwa. To na rzecz tego samego kapitalistycznego sukcesu werbowały też wszystkie przedmioty zebrane w przestrzeni moskiewskiej wystawy. Przekonywały jednocześnie do dokumentalnego pułapu filmu Eamesów. Podobnie jak i zdjęcia Nikity Chruszczowa sfotografowanego w chwili testowania amerykańskiego napoju Pepsi Cola.

Eric Schuldenfrei dla eksperymentalnego „zestawu migawek” szuka jeszcze porównania w praktykach radzieckiej szkoły montażu, zwłaszcza u Lwa Kuleszowa i, znowu, Dzigi Wiertowa. W sposobie kierowanie percepcją obrazu doszukuje się też wpływów teorii Sergieja Eisensteina[58]. Nie ma jednak śladu tych inspiracji w wypowiedziach Eamesów. Są natomiast historycznie udokumentowane przykłady pierwszych prób z projekcjami wieloekranowymi[59] w czasie światowej wystawy w Brukseli, w której Eamesowie, choć na mniej eksponowanym stanowisku niż w Moskwie, też uczestniczyli. Można więc domniemywać, że chociaż jeden $\mathrm{z}$ dwóch zaprezentowanych tam projektów widzieli, a na pewno o nim słyszeli. Pierwszy to Poème électronique, przypisywany niekiedy wyłącznie Le Corbusierowi jako nadrzędnemu pomysłodawcy pawilonu Philips Electronics, do którego audio-wizualna, „syntetyczna instalacja”[60] została przygotowana. Ze względu na specyfikę koncer-

[55] Podaję za E.L. Altimus, op.cit.

[56] E. Schuldenfrei, op.cit., s. 71.

[57] Ibidem.

[58] Ibidem, s. 74-75.

[59] Lojalnie odnotować trzeba też historycznie pierwszy eksperyment filmowy z poliwizją, który wprowadził w końcowej sekwencji Napoleona Abel Gance już w 1927 roku.

[60] I. Sykta, Ewolucja idei postępu i wizji miast przyszłości zapisana w krajobrazach, obiektach i pokazach wystaw światowych - od Brukseli 1958 do Osaki 1970, „Przestrzeń i Forma” 2014, nr 22, s. 106. 
nu zainteresowanego prezentacją najnowszych osiągnięć z pogranicza światła, muzyki i możliwości technologicznych produkowanego sprzętu równie ważny jest jednak kompozytor ośmiominutowego utworu z gatunku muzyki elektronicznej, Edgard Varèse. Przetworzone dźwięki rzeczywistych instrumentów, ale i odgłosów ludzkich czy zwierząt, wprowadzały tajemnicę, niemal rys mistyczny, transowy. Całość zawieszona była między dokonaniami awangardy filmowej, wideoartem i dzisiejszymi wizualizacjami powszechnie stosowanymi w miejscach publicznych. To, co bezpośrednio wyświetlano na wewnętrznych ścianach pawilonu, było albumem czarno-białych zdjęć poddanych obróbce za pomocą elementów animacji i koloryzacji. Możliwości interpretacyjne rosły właściwie z każdym przybyłym widzem. Ale u podstaw przekazu były różne stadia rozwoju cywilizacji ludzkiej, sygnowane różnymi obiektami kultury materialnej i duchowej, aż po ekspansję kosmosu i eksperymenty $\mathrm{z}$ energią jądrową. W tym układzie nagromadzonych danych architektura, właściwe zaplanowanie i zagospodarowanie przestrzeni, wydawała się być odpowiedzią na bolączki człowieka współczesnego[61].

Drugi projekt, o którym Charles zaczął myśleć dopiero z chwilą realizacji U.S.A. w mgnieniu oka[62], to czechosłowacki Polyekran przygotowany przez scenografa Josefa Svobodę[63] również na targi w Brukseli. Najogólniej rzecz biorąc, określano go jako system scenograficzno-demonstracyjny: na powierzchnie projekcyjne ustawione pod różnym kątem wyświetlane były zdjęcia rzeczywistych obiektów, w tym dzieł sztuki czy ludzi, dając impuls do nowej sieci połączeń. I ta powstająca architektura obrazów, które zyskują przestrzenność i przekraczają ograniczenia regularnej projekcji wydawała się celem samym w sobie. Bliżej do tak rozumianej poliekranowości będzie Eamesom w kilka lat późniejszym projekcie zaprezentowanym na wystawie światowej w Nowym Jorku.

Od makrodo mikroprojekcji i z powrotem
W skład wystawy z 1961 roku przygotowanej dla kalifornijskiego Muzeum Nauki i Przemysłu w ramach długofalowej współpracy Eamesów z IBM pt. MATHEMATICA... the world of numbers and beyond wszedł projekt filmowy oparty na odmiennym pomyśle projekcyjnym od Glimpses... i dlatego właśnie wartym przytoczenia. IBM Mathematics Peep Show widzowie oglądali w urządzeniu będącym współczesną adaptacją projektu Filippo Brunelleschiego z początku XV wieku, oryginalnie testowanego na drzwiach florenckiego baptysterium[64].
[61] Wersja linearna Poème électronique możliwa jest do zobaczenia pod tym linkiem: <https://www. youtube.com/watch? $\mathrm{v}=\mathrm{OYlBmx} 3 \mathrm{VulY}>$.

[62] Chociaż w jednym z listów przedrukowanych w An Eames Anthology znaleźć można wyznanie Charlesa: „We missed the Czech Polycran [pisownia oryginalna] at Brussels - were there the first week. Strangely enough didn't hear of it until we were well into this". An Eames Anthology..., s. 194.
[63] Na tych samych targach pokazywany był jeszcze projekt Laterna Magica w reżyserii Alfreda Radoka, który projekcji filmowych, w tym kilkukrotnych ekspozycji, używał jako demokratyczne narzędzia ekspresji na równi z ciałem aktora i tancerza. [64] Podaję za E. Schuldenfrei, op.cit., s. 109. Warto dodać, że dziś niezwykle często z tego rodzaju rozwiązaniem mamy do czynienia w muzeach filmu na całym świecie. 
Jeden z największych architektów renesansu skonstruował prostą zabawkę optyczną. Za pomocą małego otworu wywierconego w lustrze, w którym jednocześnie odbijał rysunek budowli, próbował udowodnić, że wzrok nie wychwyci różnicy między obiektem i jego przedstawieniem. Widzowie wystawy Eamesów w indywidualnych urządzeniach projekcyjnych wyposażonych w mały otwór mieli możliwość obejrzenia pięciu krótkich filmów - Something about Functions, Symetry, Topology, Eratosthenes, A Story of the Power of Numbers. Każdy dwuminutowy segment, sięgający przede wszystkim po medium animowanych rysunków Glena Flecka, zawierał jedną matematyczną zasadę. Pierwszy starał się zwizualizować relacje między przyczyną a skutkiem. Drugi koncentrował się na różnicy między potocznym użyciem pojęcia symetrii i tym obowiązującym w terminologii matematycznej. Trzeci mówił o niezmiennych właściwościach zniekształcanych obiektów. Czwarty przypominał postać starogreckiego naukowca, który jako pierwszy obliczył objętość Ziemi. Piąty przytaczał zaś legendarną historię zapłaty za wynalazek szachów, opierającej się na podwajaniu liczby ziaren pszenicy w miarę przechodzenia przez kolejne 63 pola szachownicy. Podkreślenia wymaga jednak przede wszystkim zmiana, jaka nastąpiła na poziomie warunków projekcji, którą można pokrótce nazwać przejściem od skali makro do mikro, od wielu ekranów do pojedynczego, małego wizjera. Zawężenie relacji skutkowało intymnością odbioru filmowej wizualizacji problemu, który istniał przecież $\mathrm{w}$ otoczeniu licznych interaktywnych urządzeń i zabawek ekspozycji dowodzącej, że istotą matematyki nie są liczby, ale zasady dające się uchwycić w otaczającej nas rzeczywistości[65].

W czasie wystawy światowej w Seattle w 1962 roku Eamesowie sięgnęli znów po wieloekranowość: House of Science o łącznym czasie 15 minut wyświetlany był na sześciu ekranach. Współpracujący z Eamesami Glen Fleck odpowiadał za początkową sekwencję rysunkowej animacji, która piętrzyła przed widzem historię nauki rozumianą jako relacja człowieka do otaczającej go architektury. Sekwencja rysunkowa podkreślała zależność powstających tytułowych „domów” od obszarów naukowej potrzeby poznania. Wskazywała na istnienie związku przyczynowo-skutkowego między sposobem rozumienia świata przez człowieka a poszerzającą się pulą obiektów, które nie są wyłącznie schronieniem i nie są też miejscami kultu. W całym filmie podkreślana jest też ogólniejsza relacja między tym, co w środku człowieka i co wokół niego, odpowiedzialna za dwa wzajemnie uzupełniające się wektory naukowej ciekawości. Cezurę przeszłości wyznacza przejście od animowanych rysunków do zdjęć. Miniaturowe wcześniej postaci ludzkie zastąpione zostają przez pełnoprawne wizerunki naukowców poruszających się we wszystkich możliwych obszarach badań: od planety, kosmosu, rozmaitych zjawisk przyrodniczych po zwierzęta.

[65] Por. K. Gallerneaux, Squaring the hypothetical circle: Getting around mathematica, [w:] The World of

Charles..., s. 277. 
Naukowcy stosują odmienne metodologie, sposoby zapisu, publikacji wyników oraz różne narzędzia dydaktyczne. Tworzą sieć naukowych połączeń, która stanowi elementarny, pierwotny „dom nauki”.

Rezygnację z filmu animowanego na rzecz fotosów i fragmentów filmowych w House of Science można rozumieć też nie na sposób symboliczny, ale jako przejaw pragmatyzmu Eames Office. Użycie rysunków może być wyrazem niechęci do sięgnięcia do archiwów zewnętrznych z powodów czysto praktycznych: ogromna kolekcja zdjęć, jaką zgromadzili Eamesowie, była przez nich stale aktualizowana i rozbudowywana, ale skupiała się właśnie na tym, co tu i teraz. Lotte Johnson pisze o nieustającej praktyce przeorganizowywania posiadanych zbiorów i wprowadzania do nich nowych pozycji, będących pokłosiem prywatnych i zawodowych podróży[66]. To one stanowiły bazę wyjściową do opowiadania przede wszystkim za pomocą zdjęć już wykonanych, kawałków świata sfotografowanego i wprowadzonego do podręcznej biblioteki. Również kolejny koncept projekcyjny, Think, można widzieć jako kolekcję obrazów Eamesów wykorzystanych we wszystkich wcześniejszych projektach filmowych, jako bank pamięci[67].

Think czyli jak rozwiązać problem
W przypadku wystawy światowej w Nowym Jorku w 1964 roku, drugiej po moskiewskiej najczęściej wymienianej jako najbardziej spektakularna odsłona filmowego dorobku Eamesów, do głosu doszła kumulacja dotychczasowych doświadczeń z wieloekranowymi projekcjami. Marius Nedelcu twierdzi zresztą, że wszystkie wystawy światowe organizowane między 1958 a 1970 rokiem stanowiły ważny katalizator dla kreatywnych poszukiwań i eksperymentów prowadzonych w ramach kina[68]. Wlicza się w ich poczet również pomysły Eamesów, chociaż te przynależały w pierwszym rzędzie do świata wielkich przedsiębiorstw sprzedających nowoczesne technologie, następnie do świata nauki i informacji, a dopiero na końcu do kina.

„Migawki” tym razem zastąpiła „myśl”. Wielokanałowa prezentacja filmowa wyświetlana w ramach targów nosiła tytuł Think i była częścią konsekwentnie rozbudowywanego od lat multimedialnego interfejsu IBM. O czym pisze Schuldenfrei, słowo „think” miało zasłużoną historię użycia $\mathrm{w}$ jednym $\mathrm{z}$ najstarszych przedsiębiorstw informatycznych na świecie. Jako korporacyjny slogan IBM wykorzystywał go już co najmniej od 1914 roku[69], ale ciągnęła się za nim też wykładnia negatywna: było ostrzeżeniem-reakcją na wszystkie nieprzemyślane i nielogiczne zachowania pracowników[70].

Podobnie jak w opisie Glimpses..., tu też ważne jest samo środowisko nowojorskich targów światowych, które osadza wieloekranowy
[66] L. Johnson, Celebrating connections: from Aby Warburg's 'Iconology of the Interval' to the New Kinds of Models' of Charles and Ray Eames, [w:] The World of Charles..., s. 215-216.

[67] E. Schuldenfrei, op.cit., s. 171.
[68] M. Nedelcu, Expanded image spaces. From panoramic image to virtual reality, through cinema, „Close Up: Film and Media Studies” 2013, vol. 1, no. 1, s. $44-53$.

[69] IBM zostało założone w 1911 roku.

[70] E. Schuldenfrei, op.cit., s. 162-163. 
projekt Eamesów w ramie współczesnych dokonań swojej epoki. W filmie podsumowującym fenomen i zasięg światowych targów w Nowym Jorku w 1964 roku pojawia się kluczowe stwierdzenie, że były to targi mentalnie ulokowane jeszcze w latach pięćdziesiątych[71]. Byłaby to więc jedna z nielicznych wystaw światowych zapatrzona w przeszłość zamiast w przyszłość? Komentarze takie związane były przede wszystkim ze strategicznymi decyzjami podejmowanymi przez głównego nowojorskiego urbanistę, odpowiedzialnego za, niejednokrotnie krytykowane, strukturalne zmiany zabudowy tego miasta, Roberta Mosesa, jednocześnie komisarza wystawy. Moses uczestniczył już w organizacji przedwojennej światowej wystawy nowojorskiej z 1939 roku i to ona przede wszystkim stanowiła dla niego punkt odniesienia i odpowiadała za ambicję zdublowania historycznego sukcesu[72]. Ale Ameryka się zmieniła, ale reakcji na te zmiany trudno w wystawie szukać. To kraj po zabójstwie prezydenta Johna Kennedy’ego, uwikłany w wojnę w Wietnamie, konfrontujący się z zamieszkami na tle rasowym i będący świadkiem kiełkowania, właśnie w Nowym Jorku, ruchu hippisowskiego[73]. Nie znajdziemy śladów tych procesów w pomyśle na Expo, chociaż być może już sama idea targów światowych nie daje takich możliwości. Targi omijają teraźniejszość, by na nieodległą przyszłość rzutować technologiczne innowacje. Jednak głównym problemem związanym ze stylem samodzielnego zarządzania Mosesa, zarzutami o niegospodarność i jego niechęci do spełnienia wymagań stawianych przez centralne biuro targów światowych w Paryżu (Bureau international des expositions) był ostateczny brak akceptacji ze strony tej instytucji, wstrzymanie finansowania i publiczne zalecenie niepartycypowania w targach. Dostosowały się do niego niemal wszystkie państwa europejskie zrzeszone w radzie targów oraz Kanada, Australia i Związek Radziecki[74].

Kiedy dzisiaj czyta się o wystawie światowej z 1964 roku, to na plan pierwszy poza Robertem Mosesem wysuwa się nazwisko Walta Disneya[75]. Dzięki jego obecności i niewielkiej reprezentacji innych państw targi nowojorskie stały się sceną przede wszystkich amerykańskich nowinek technicznych, poligonem badawczym przed kolejno otwieranymi parkami rozrywki. Należały do nich zwłaszcza wciąż jeszcze testowane i ulepszane przez Disneya, i już będące przedmiotem jego dumy, „audio-animatronicsy”, elektronicznie animowane protoroboty o powłoce przypominającej postaci z gabinetu figur woskowych. Posia-

[71] The 1964 World's Fair, reż. Rich Hanley (1996), <https://www.youtube.com/ watch?v=WRTBET 7 DUkc $>$, dostęp: 1.03.2020.

[72] Jego polityka przebudowy Nowego Jorku porównywana była niejednokrotnie z działaniami Georges’a Haussmanna na rzecz Paryża.

[73] J. Mrozek, Geneza i rozwój subkultury hipisów w Stanach Zjednoczonych (wybrane konteksty), „Studia Edukacyjne" 2017, nr 45, s. 240.
[74] Targami, do których się przygotowywano były o trzy lata późniejsze targi w Montrealu. Por. między innymi R.A. Caro, The Power Broker: Robert Moses and the Fall of New York, Vintage 1975.

[75] Por. między innymi A. Ndalianis, Disney's utopian techno-futures tomorrow's world that we shall build today, [w:] Tourist Utopias: Offshore islands, enclave spaces, and mobile imaginaries, red. T. Simpson, Amsterdam 2017, s. 143-165. 
dały pewne zdolności ruchowe i werbalne, ale był to efekt aktywności podejmowanych przez ludzkiego animatora podłączonego do urządzeń rejestrujących i ich zapisu na taśmie magnetycznej. Szczegółowo opisuję jeden $\mathrm{z}$ fenomenów Expo, ponieważ również w pawilonie IBM $\mathrm{w}$ formule teatrzyku o matematycznym podtekście pt. Sherlock Holmes in the Singular Case of the Plural Green Mustache, za który odpowiadali Eamesowie, pojawiały się jakże inne od Disneyowskich wciąż jednak marionetki. Umowne, tchnące myszką płaskie figury pod warstwą wierzchnią ukryte miały efektowne mechanizmy z rozjarzonymi żarówkami, poza walorem estetycznym bez żadnej jednak praktycznej funkcji technicznej. Ta konfrontacja jest kluczowa dla zaobserwowania podstawowej różnicy dzielącej poszukiwania Disneya i Eamesów, niedającej się ograniczyć tylko do poruszających się lalek. Kiedy w innych pawilonach Disneyowskie roboty pełniły funkcję atrakcji samej w sobie, jedynie bardziej wytrwałym obserwatorom dając możliwość wysondowania w nich tęsknoty za sztucznym człowiekiem[76], w pawilonie IBM funkcjonowały $\mathrm{w}$ ścisłym sprzężeniu $\mathrm{z}$ edukacyjnym przekazem całej przestrzeni ekspozycyjnej i jej poszczególnych stanowisk. Temat wystawy - „Pokój przez zrozumienie” („Peace through Understanding”) - choć nacisk kładł na edukację naukową, koncepcję nauczania ustawicznego (life long learning) oraz technologię kosmiczną, to ostatecznie legitymizował przede wszystkim komercyjne i biznesowe aktywności organizatorów[77]. Pawilon IBM był tu jednym z miejsc wyjątkowych pod kątem spełniania dyrektywy tematycznej targów, w praktyce zdystansowanym jednak przez park dinozaurów czy Futuramę II, poprawioną wersję instalacji General Motors z 1939 roku, przenoszącej widzów w przyszłość do 2064 roku[78]. O wymiarze organizacyjnego chaosu i braku ostatecznej idei mogła świadczyć też wypożyczona z bazyliki św. Piotra z Rzymu Pieta Michała Anioła.

Za projekt budynku odpowiadał Eero Saarinen[79], a za wnętrza Charles Eames. Jak pisze architektka Iwona Sykta, pawilon IBM przyjął formę owalnego teatru $\mathrm{z}$ lasem stalowych kolumn: pni i listowiem Z 14 tysięcy zielono-szarych paneli. Budynek był wystawiony na oddziaływanie pogody, a wliczona w koszty korozja miała nadać całości naturalny, choć nieco apokaliptyczny wygląd[80]. Powierzchnia pawilonu pokryta była próżniowymi, przestrzennymi literami tworzącymi wielokrotnie powtórzony napis IBM. Eliptyczny kształt pawilonu - stąd i nazwa The Ovoid Theatre - zadecydował o konieczności montażu ekranów pod różnym kątem nachylenia, odgórnie determinował złożone warunki projekcyjne.

[76] Por. między innymi E. Schuldenfrei, op.cit.,

s. 177 .

[77] P. Greenhalgh, Fair World: A history of world's fairs and expositions from London to Shanghai 1851-2010, Winterbourne 2011, s. 36. Podaję za I. Sykta, op.cit., s. 108 .
[78] I. Sykta, op.cit., s. 110.

[79] Informację podaje między innymi Iwona Sykta, chociaż zdaję sobie sprawę z faktu, że w roku 1964 Saarinen już nie żył. Por. I. Sykta, op.cit., s. 109.

[80] Ibidem, s. 109-110. 
Całościowy projekt Eamesów gwarantujący multisensoryczne doświadczenie nosił nazwę Information Machine, w geście rozwinięcia dwóch liter skrótowca IBM, z którego tym samym wymazano nieneutralne skojarzenie z działalnością komercyjną. Żeby wejść do środka, widzowie musieli pokonać labirynt pomostów, będących w stanie utrzymać ponad 1000 osób jednocześnie. We wnętrzu „maszyny informacyjnej" zwiedzający kierowani byli na tak zwaną ścianę widzów (People Wall[81]): 12 rzędów zaopatrzonych w poręcze, $\mathrm{z}$ których każdy był w stanie pomieścić około 35 ludzi[82]. Nazwa delimitowała przestrzeń ekranów i odbiorców, ale podkreślała też sieć połączeń, techniczno-ludzkie sprzężenie. Jak pisze Schuldenfrei, przestrzeń wystawiennicza pawilonu została przygotowana z myślą o procesie wymiany wiedzy[83].

Po wypełnieniu się sali i zamknięciu drzwi pojawiał się nowy w perspektywie dotychczasowych doświadczeń Eamesów czynnik ludzki, mobilny narrator. Było w nim coś zarówno z gospodarza, jak i kolejnej modyfikacji ekranu projekcyjnego: tym razem $\mathrm{z}$ rejestru fantazji karnawałowych czy cyrkowych [84]. Prezenter występował też jako mistrz ceremonii, przewodnik po nowoczesnej epoce informacji[85], który poprzez swoją fizyczną obecność wprowadzał domniemanie jakości związanej z zapowiedzią projekcji trójwymiarowej. Chociaż nie był widzialny przez cały czas trwania projekcji, był wysłannikiem korporacyjnego producenta idei. Poruszał się między ekranami na ruchomej platformie i zwracał się do widzów tylko w tych momentach, w których potrzebny był kontekstualny komentarz. Był więc przewodnikiem oferującym wskazówki percepcyjne. Dodatkowe, fakultatywne wyposażenie widza stanowiły słuchawki z symultanicznym tłumaczeniem kwestii wypowiadanych przez prezentera na język niemiecki, japoński, włoski, francuski, hiszpański[86].

Widzowie tuż po zajęciu miejsc byli informowani o tym, że ściana widzów za pomocą windy hydraulicznej podniesiona zostanie w górę i ulegnie odchyleniu pod kątem 45 stopni. Widzowie znajdowali się bezpośrednio naprzeciw 22 ekranów, z których większość miała tradycyjny prostokątny kształt, ale były wśród nich też okrągłe, trójkątne i trapezoidalne płaszczyzny projekcyjne. Drzwi wejściowe były blokowane po to, by do środka nie przenikały odgłosy (i światła) pozostałych stanowisk wystawy. Dopiero wtedy gospodarz wygłaszał performatywne i kluczowe dla każdego spektaklu słowa: „Ladies and gentlemen, welcome to the IBM Information Machine”. Rozpoczynała się właściwa projekcja Think. Wielokanałowy przekaz pokazywany był na

[81] Dlatego też film Eamesów, który w formie linearnej uwiecznia projekcję realizowaną niemal bez przerwy w przestrzeni nowojorskich targów, nosi tytuł View from the People's Wall. Powstał w 1966 roku jako forma zabezpieczająca przetrwanie chociaż jednościeżkowej wersji przeznaczonej dla tych, którzy do pawilonu nie dotarli, jak i dla przyszłych pokoleń. A. Galick, Think, [w:] The World of Charles..., s. 289.
[82] Ibidem, s. 287.

[83] E. Schuldenfrei, op.cit., s. 162.

[84] Można w tym doszukiwać się oczywiście nawiązania do praktyk kina niemego, do mediowania między obrazem a widzem.

[85] E. Schuldenfrei, op.cit., s. 168.

[86] A. Galick, op.cit., s. 289. 
piętnastu centralnych ekranach. Wśród nich na dziewięciu wyświetlano fragmenty filmowe, a na sześciu pozostałych towarzyszące pokazy slajdów. Siedem dodatkowych płaszczyzn projekcyjnych domykało całość stroboskopowo wyświetlanymi światłami i kolorami. Koncepcyjny sposób wykorzystania wieloekranowości, wbrew temu, co krytycznie opisywał choćby Paul Schrader[87], zapewniał stopniowanie przekazu. Amy Gallick twierdzi, że tylko jeden lub dwa ekrany przedstawiały wizualne wtrącenia, podczas gdy dominował jeden przekaz centralny, choć ze względu na wykorzystanie wszystkich powierzchni jednocześnie na pewno fundował widzowi efekt splitscreenu. Za przykład niech posłuży scena meczu amerykańskiego futbolu: równolegle na sześciu ekranach pokazywany był trener przekazujący zebranej drużynie wskazówki taktyczne, tablica z rozrysowaną strategią gry, słuchająca go drużyna, akcja rozgrywająca się na boisku, scena zwarcia drużyn, akcja pojedynczego zawodnika. Każda ścieżka filmowa fotografowana była w różnym planie i z różnej perspektywy. Istniała zresztą w Think zależność między pozycją ekranu, kątem jego pochylenia a kątem widzenia kamery w użytym materiale [88].

Mozaikowość i wielozmysłowość kanałów niezbędnych do odbioru tego projektu, nawet po latach jednak daje się we znaki. W różnych opracowaniach natrafić można na odmienne ustalenia dotyczące liczby ekranów, kiedy ich ostateczny wynik to 22 płaszczyzny projekcyjne. Zmiksowane logotypy, znaki, schematy, modele i obiekty przedstawiane z kilku punktów widzenia jednocześnie, nawet przy współudziale mediatora, mistrza tej ceremonii, mogły przytłaczać widza. Obrazy zmieniały się w rozpoznawalnym dla Eamesów trybie jedno- i kilkusekundowym. Cały przekaz stopniem intensywności i rozproszenia dorównywał dzisiejszej codzienności informacyjnej.

Największym wyzwaniem prezentacji była synchronizacja ściany widzów, trajektorii ruchów gospodarza i systemu projekcyjnego[89]. Żeby nie doprowadzać do nieprzewidzianych, technicznych przerw, materiał wyświetlany był w pętli. Stała sekwencja elementów - wprowadzanie gości, tłumaczenie zasad, oficjalne powitanie, docelowa projekcja - była zaplanowana na 20 minut. W ciągu targów dziennie w pokazie uczestniczyło 16 tysięcy widzów[90].

Wspólnym obszarem tematycznym tego eksperymentu z zakresem widzenia i zdolnością rejestracji różnych komunikatów podawanych w niestandardowej formie były techniki rozwiązywania problemów („a Statement about Problem Solving and Abstract Models”[91]). Ich przedział zawierał się między tymi wymagającymi myślenia w skali

[87] Por. między innymi wypowiedzi reżysera w filmie Eames: The Architect and the Painter. Gdyby chcieć wyciągnąć $\mathrm{z}$ tego jakiś wniosek, nietrudno byłoby ulokować $\mathrm{w}$ takim właśnie środowisku audiowizualnym bohatera najsłynniejszego scenariusza autorstwa Paula Schradera, Travisa Bickle’a z Taksówkarza (1976).
[88] Ibidem.

[89] Ibidem.

[90] Ibidem.

[91] Taka informacja znajduje się w napisach początkowych filmu View from the People's Wall (1966). 
totalnej jak planowanie miasta, mniejszej jak przygotowanie planu rozmieszczenia gości w czasie domowego przyjęcia, aż po prozaiczną decyzyjność w przestrzeni kuchni. Kluczem do sukcesu było uwzględnienie zawczasu wszystkich możliwych czynników wspierających podejmowane decyzje, ale i zapobiegających potencjalnym konfliktom i kryzysom. Od odbiorców oczekiwano aktywnej interpretacji materiału prezentowanego na ekranach. Nie było jednego idealnego wzoru odbioru. Schuldenfrei zrównuje percepcję widza z sytuacją przechodnia idącego przez gwałtownie zmieniający się krajobraz wizualny[92]. Skomponowany z matrycy obrazów wyświetlanych równocześnie na ekranach o różnym formacie testował ludzki system operacyjny, to, w jaki sposób umysł używa i łączy dostarczane informacje. Żeby rzeczywiście ocenić przebieg reakcji pojedynczego widza, potrzebne byłyby ankiety, a takie, o ile mi wiadomo, nie były przeprowadzane. Nie wydaje się jednak, żeby Eamesowie arbitralnie zakładali informacyjną porażkę widza, którego nieustannie chcieli edukować. Demokratyzacja przekazu oznaczała nieostateczną sytuację percepcyjną, w której różne wątki mogą zostać przechwycone przez widzów w odmienny sposób. Rewolucyjny aspekt takiego podejścia wiązałby się z przekonaniem, że nie ma jednego, ostatecznego i rozstrzygającego znaczenia. Ekrany w pawilonie wystawienniczym były efektem eksterytoriaryzacji sieci skojarzeń, połączeń obrazów, komunikatów. Nie było jednego poprawnego modelu recepcji, ważny był sam proces.

Przez cały okres twórczości designerskiej Ray i Charles Eamesowie sięgali po film. Najpierw używali go do dokumentowania swojej działalności twórczej, potem do realizacji zleceń reklamowych, aż dotarli do wielkobudżetowych projektów multimedialnych o zasięgu globalnym, których nadawcą były podmioty państwowe i korporacyjne. We wszystkich tych działaniach filmowych wykazali się nowatorskim podejściem, negocjującym dotychczasowe metody realizacji. Za każdym razem potrafili stworzyć nową jakość. Zrewolucjonizowali film reklamowy i edukacyjny. I w żadnym z tych gatunków nie rezygnowali z podejścia humanistycznego. Stworzyli ofertę wiedzy naukowej pod postacią rozrywki na najwyższym poziomie.

Eamesowie po wystawie nowojorskiej nie wrócili już do pomysłu projekcji wieloekranowych. Przede wszystkim ten model przekazu zaczął kojarzyć się z rozrywką pozbawioną istotnych treści edukacyjnych[93]. Lata sześćdziesiąte były pochodem licznych projekcji wieloekranowych na kolejnych targach Expo i w parkach Disneya. W projektach innych twórców następowało rozcieńczenie innowacyjnego pomysłu[94]. Eamesowie zrezygnowali więc z czegoś, co stało się zbyt popularne. Wieloekranowość byłaby więc jedynie przejściowym stadium wizualizacji sieci informacyjnych połączeń, od którego ostatecznie odeszli, wypatrując już następnego etapu. Byli otwarci na przy-

[92] E. Schuldenfrei, op.cit., s. 133.

[94] Ibidem.

[93] Ibidem. 
szłość zmieniających się technologii, nowych ofert dystrybucji treści i możliwości dostępu. Już w pierwszej połowie lat siedemdziesiątych interesowali się możliwościami upowszechniania wiedzy poprzez telewizję kablową. W 1972 roku zrealizowali dla korporacji publicznych nadawców (Corporation for Public Broadcasting) film Cable: The Immediate Future (1972)[95]. Byli przekonani, że sieć połączeń telewizyjnych stwarza warunki powszechnej komunikacji i daje największy dostęp do informacji. Właściwie już wtedy byli gotowi na przyjście ery Internetu.

B I B L I O G R A F I A
Altimus E.L., Out of many, one: Glimpses of the USA by Charles and Ray Eames, The Family of Man by Edward Steichen, and universal thought in cold war propaganda, 2012, <https://digitalcommons.lsu.edu/gradschool_theses/2892>, dostęp: 21.12.2019

An Eames anthology. Articles, film scripts, interviews, letters, notes, speeches by Charles and Ray Eames, red. D. Ostroff, New Haven, London 2015

Colomina B., Domesticity at War, Cambridge, Mass., London 2007

Harwood J., The Interface IBM and the Transformation of Corporate Design 19451976, Minneapolis, London 2011

Kirkham P., Charles and Ray Eames. Designers of the twentieth century, Cambridge, Mass., London 1998

Meet Me at the Fair. A World's Fair Reader, red. L. Hollengreen, Pittsburgh 2014

Mrozek J., Geneza i rozwój subkultury hipisów w Stanach Zjednoczonych (wybrane konteksty), „Studia Edukacyjne” 2017, 45, s. 237-253

Nedelcu M., Expanded image spaces. From panoramic image to virtual reality, through cinema, "Close Up: Film and Media Studies" 2013, 1, s. 44-53

Neuhart M., Neuhart J., Eames R., Eames Design: The work of the office of Charles and Ray Eames. London 1989

Schrader P., Poetry of ideas. The films of Charles Eames, "Film Quarterly" 1970, 23, s. $2-14$

Schuldenfrei E., The Films of Charles and Ray Eames: A universal sense of expectation, Routledge 2015

Sykta I., Ewolucja idei postępu i wizji miast przyszłości zapisana w krajobrazach, obiektach i pokazach wystaw światowych - od Brukseli 1958 do Osaki 1970, „Przestrzeń i Forma” 2014, 22, s. 103-122

The World of Charles and Ray Eames, red. C. Ince, L. Johnson, London 2018

Weems J., Vision at California scale, Charles and Ray Eames, systems thinking and the diminishing status of the human body after World War II, [w:] V. Janssen, Where Minds and Matters Meet. Technology and California in the West, Berkeley, CA, 2012

[95] Zob. film Cable: The Immediate Future (1972) reż.

Charles and Ray Eames, Glen Fleck. 